\title{
Alejandro Parra and Dante's Eighth Circle of Hell
}

\author{
Etzel Cardeña
}

Lund University

Etzel.Cardena@psy.lu.se

Submitted June 29, 2021; Accepted June 30, 2021; Published September 15, 2021

https://doi.org/10.31275/20212243

Creative Commons License CC-BY-NC

Abstract-This commentary places Alejandro Parra's very long list of plagiarisms and data misrepresentations within the context of Dante's classification of human foibles. The responses from two Argentinean universities are described, along with continuing examples of Parra's misrepresentations.

\section{Questa a peccar con esso cosi venne, \\ Falsificando sé in altrui forma}

(from Canto XXX of Dante's Inferno)

It is telling that Dante, in his analysis of humanity, places topographically and morally those accused of fraud and deceit in the eighth lowest circle of hell, surpassed in iniquity only by the betrayers. He found abhorrent, as the quotation above marks, those who fraudulently pass themselves as others. It is not a stretch to surmise that those who trade others' wares as their own would also reside in the "evil trenches" (Malebolge) in this circle. Those so condemned may spend eternity scratching their leprosy lesions, a metaphor for how fraud corrupts, turning something clean into something impure (https://www.oed. com/view/Entry/42035? rskey=GQf5vf\&result=2\#eid).

Alejandro Parra's repeated, chronic plagiarisms and data misrepresentations (e.g., to duplicate an interview creates false data, doubling the number of observations and making them international), as Michael Nahm (2021) has painstakingly documented, should be taken with all the seriousness they deserve, even if we no longer believe in a literal hell along the lines of what the character Dante saw under 
the guidance of Virgil. A plagiarist steals someone else's clean and hardearned work and passes it off as his/her own, attempting to deceive everyone, and as a result casts doubt on other publications in the field (I agree with Dr. Nahm that all of Parra's work should be considered questionable unless determined to be otherwise). Parra's misdeeds will be injurious to parapsychology, an area of study in which critics will be eager to pounce on the revelations and say something like "I told you so, psi supportive findings are nothing more than errors and fraud," even though the latter is not more common in parapsychology than in other scientific areas (Roe, 2016). And the critics will have a kernel of truth in this particular case because it seems that Parra has had enablers. Nahm wrote that he found out third-hand that some people in the field had had knowledge of Parra's plagiarism for a while. In a recent exchange I had with a past journal editor, s/he wrote that Parra had been "repeatedly warned" about not continuing to plagiarize, which implies that some people knew about it and did not make public his infractions. We ought to get public explanations from those who were aware of Parra's misdeeds and did not act immediately and decisively as was, in my opinion, their ethical and scientific duty.

As of the date of my writing this comment, I am not aware that Parra faces civil or criminal charges, which would not be unheard of (cf https://www.plagiarism.org/blog/2017/10/27/is-plagiarism-illegal), yet his academic free ride seems to be over thanks to the work by Nahm, Braude, and others. When I first found out from various sources about the enormity of Parra's deception, I contacted the Bial Foundation (I am a member of its Scientific Advisory Board) and let them know. They then withdrew a grant offered to Parra. He has also been expelled from the Parapsychological Association (PA), whose Board of Directors rightly concluded that his misdeeds will damage the PA and the field at large (cf Parra, 2021). In addition, four researchers whose work was plagiarized by Parra, including Christopher Kerr, Doreen Westera, and me (in reference to two chapters from a book I coedited, Bentall, 2000; Marks, 2000) wrote in Spanish to the university that granted him a Ph.D. (based on a dissertation with substantial instances of plagiarism) and to the university that was employing him. The authorities of the first one, Universidad de Ciencias Empresariales y Sociales, from Rector O'Donell to Dean Said, did not even acknowledge the two emails we sent them. 
The response of the second university, Universidad Abierta Interamericana, was the polar opposite. From the beginning they contacted us and promised to initiate a thorough and serious investigation of the case. While they were conducting it, Parra contacted the legal division of the university, which recommended dismissing him summarily from all programs and activities at the university, something that has come to pass. And future publication of at least some of his books has been cancelled.

So perhaps now Parra would be expected to repent and avoid further damnation? Do not count on it. Heraclitus (535-475 BCE) is now our guide. His fragment 119 (John Burnet, Arthur Fairbanks, \& Kathleen Freeman, Trans.; https://antilogicalism.files.wordpress.com/2016/12/ heraclitus_fragments_final.pdf) states that “Man's character is his fate." Parra continued lying about one of his submissions to the JSE even after being found out (Braude, 2021), and there is more. . . In an exculpatory letter, Parra (2021) described himself as "victimized" by the investigation of his plagiarism and the ensuing consequences. To make his argument air-tight he cited a supporting message by "Andres Tocalini, MD, Decano de la Facultad de Psicologia y Relaciones Humanas Universidad Abierta Interamericana." The only problem being that Tocalini, a close collaborator of Parra, is not an MD but a priest (according to his Linkedln profile), and is not nor has ever been a Dean (Decano) of that university, something that of course Parra had to know. An aspect Dante noted in his visit to the eighth circle was the stench coming out of the corruption of its denizens ...

\section{REFERENCES}

Bentall, R. P. (2000). Hallucinatory experiences. In E. Cardeña, S. J. Lynn, \& S. Krippner (Eds.), Varieties of anomalous experience (1st ed., pp. 85-120). American Psychological Association.

Braude, S. E. (2021). Parra and the JSE. Journal of Scientific Exploration, 35(3), 620-621. Marks, L. E. (2000). Synesthesia. In E. Cardeña, S. J. Lynn, \& S. Krippner (Eds.), Varieties of anomalous experience (1st ed.). American Psychological Association.

Nahm, M. (2021). A new case of scientific dishonesty in the field of parapsychology. Journal of Scientific Exploration, 35(3), 623-638.

Parra, A. (2021, March 8). A plagiarism case associated with Parra's papers: An honest reply and clarification. Email letter.

Roe, C. A. (2016). The problem of fraud in parapsychology. Mindfield 8(1), 8-17. 